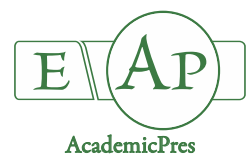

\title{
Temporary Immersion System for Micropropagation of Tree Species: a Bibliographic and Systematic Review
}

\author{
Lara S.O. CARVALHO ${ }^{1 *}$, Elif A. OZUDOGRU², Maurizio LAMBARDI ${ }^{3}$, \\ Luciano V. PAIVA ${ }^{4}$ \\ ${ }^{1}$ Federal University of Lavras, Biology Department, Lavras, PO Box 3037, Brazil; lcarvalho470@gmail.com (*corresponding author) \\ ${ }^{2}$ Biyofidan Plant Tissue Culture Laboratory, Yalova, Turkey; elifaylinozudogru@yahoo.it \\ ${ }^{3}$ IVALSA / Istituto per la Valorizzazione del Legno e delle Specie Arboree, CNR, Sesto Fiorentino, Florence, Italy; lambardi@ivalsa.cnr.it \\ ${ }^{4}$ Federal University of Lavras, Chemistry Department, Lavras, PO Box 3037, Brazil; luciano@dqi.ufla.br
}

\begin{abstract}
This paper was characterized by a bibliometric and systematic review on the database ISI Web of Science, aiming to provide an update of the main points addressed regarding the Temporary Immersion Systems (TIS) for micropropagation of tree species. It was pointed out that the frequency and time of immersion were one of the main parameters studied in the papers and $35 \%$ these papers worked with eucalyptus species. The main problem reported in the papers was the hyperhydricity, but it was overcome via procedures such as: a) air injection into the system, b) increasing the immersion intervals and decreasing the immersion time and c) decreasing concentration of cytokinin. Most papers reported that TIS produced plants that were more successful in surviving the ex-vitro acclimation stage than those produced on semi-solid media or continuous immersion systems. Few studies compared different types of temporary immersion bioreactors on micropropagation of plants and within the established criteria, papers with TIS tree species represented only $15 \%$ of the total. This system has presented promising results for most of the tree species, and although some gaps have been identified and few are the works with tree species, this process has been taking an increasingly larger space in the propagation of plants.
\end{abstract}

Keywords: eucalyptus; hyperhydricity; immersion frequency; micropropagation

\section{Introduction}

Micropropagation of plants in vitro using liquid culture media are considered to be more effective than semi-solid culture media because, in the liquid systems, plants have greater accessibility to the medium components, allowing greater gains in biomass and time reduction for plants propagation; moreover, there are ease of handling, possibility to scale and automate (which reduces labor costs), besides not having expenses with gelling agents - one major component increasing the cost of propagation in commercial laboratories (Dutra et al., 2009; Oliveira et al., 2011b; Welander et al., 2014; Businge et al., 2017).

Among the systems that use the liquid medium, the Temporary Immersion System (TIS), allowing the temporary contact between the plants and the liquid medium, presents advantages such as to avoid continuous immersion, which adversely affects growth and morphogenesis of plants, and provide adequate oxygen transfer to the culture (Etienne and Berthouly, 2002).
Tree species of great economic interests need efficient multiplication at the in vitro stage to obtain sufficient numbers of plants for production purposes, and although many of them already have well-established propagation systems, the liquid culture using TIS is an alternative method that has shown advantages for some of these species when compared to the conventional method of micropropagation, which uses semi-solid medium (Akdemir et al., 2014; Vilchez and Albany, 2015; Businge et al., 2017).

As for the aforementioned, this study aims at performing a bibliometric and systematic review of the literature in the sector, focusing the attention to the main contributions related to liquid culture in TIS of tree species.

\section{Temporary Immersion System (TIS): An Overview}

Liquid culture in TIS is an automated system, designed for intensive and often scaled-up cultures, able to monitor and control micro-environmental conditions, improving the supply of nutrients and gas transfers, in order to reduce 
270

physiological disorders, such as hyperhydricity and, thus, preserve the morphological integrity of micropropagated cultures. This system provides an in vitro environment for plants tissue and organ cultures, where the cultivated propagules are immersed for a certain period into a liquid medium and then exposed to a gaseous environment (Georgiev et al., 2014). They are semi-automated or fullyautomated cultivation systems, based on alternating cycles of temporary immersion of the cultured plant tissue into the liquid medium followed by draining and exposing the plant tissue to a gaseous environment.

The immersion period is usually shorter (a few minutes), whereas the air exposure period is prolonged (several hours). The precise control of the frequencies and time of immersion may significantly reduce the hyperhydricity of the plant tissue by creating conditions for optimal humidity and nutrient supply (Albarrán et al., 2005; Georgiev et al., 2014).

In the TIS the direct exposure of the plant tissue to the gaseous environment facilitates the interphase oxygen transport from the gas to the cultured cells, which doesn't occur in submerged cultures, where the interphase oxygen transport faces resistance in a few boundary layers [gasliquid and liquid-solid interfaces]. In this way the improved oxygen transport contributes to better gas exchange, reducing oxygen limitations and, thus, lowering the occurrence of physiological disorders such as asphyxia and hyperhydricity (Georgiev et al., 2014).

The existent types of TIS differ in relation to the size of the container, type of culture support, presence of computerized immersion control or of a simple timer, use of a peristaltic pump or an air pump or mechanical motion of the container to displace the liquid, recycling or not of the medium, and separation or incorporation of the medium tank with the culture container (Etienne and Berthouly, 2002).

\section{Bibliometric and Systematic Review}

Literature review papers are "a form of research that uses sources of bibliographic or electronic information to obtain search results from other authors, in order to theoretically supports a particular topic" (Botelho et al., 2011).

In bibliometric reviews, there is the quantification of publications related to a topic under study, that is, frequency of publications over the years, authors, journals, countries, and other important data. In contrast, systematic reviews are in-depth analysis that deals with a particular research issue by using detailed, explicit and systematic methods to raise, identify, select, interpret, collect and analyze references (Botelho et al., 2011).

According to Whittemor and Knafl (2005), there are basically four types of systematic literature review: metaanalysis (a combination of results of studies with statistical formulas, targeting analysis, comparisons and generating new results); systematic (based on scientific research strategies, it limits the scope of selection of papers, synthesizes studies and evaluates them critically); qualitative (systematization and synthesis of qualitative studies' findings, transforming them into tools to build new theories), and integrative (reviews the past empirical and theoretical literature, presenting the state of the art on a theme, especially for results analysis and synthesis of previous research contributions and gaps). In this particular study, a bibliometric review, followed by a systematic literature review, was selected and carried out.

\section{Materials and Methods}

This study is characterized as a descriptive research, drawn by a bibliometric and systematic review focusing on investigating the main parameters related to the study of TIS in tree species. Fig. 1 highlights the research design.

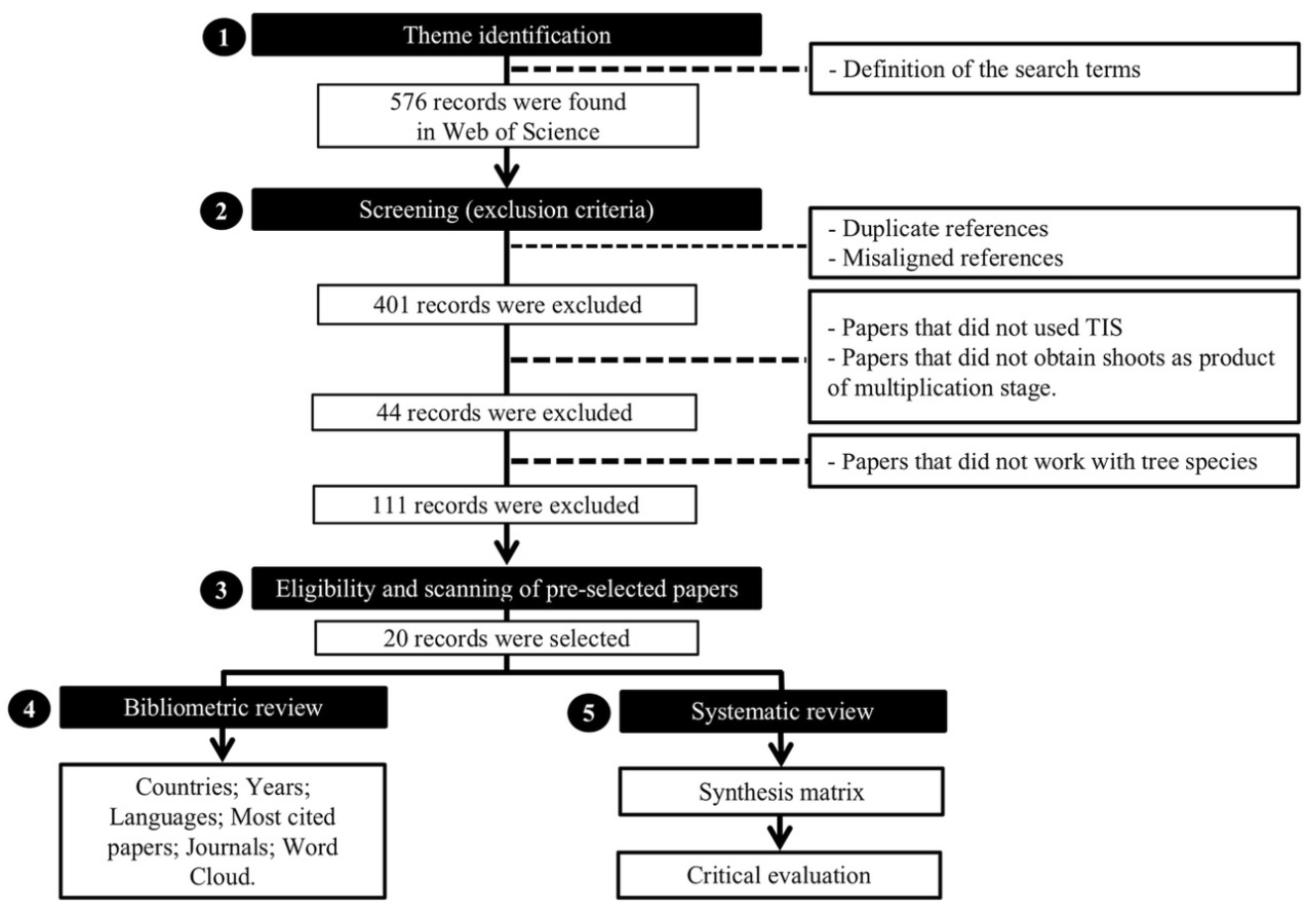

Fig. 1. Flow diagram of the study selection process for the bibliometric and systematic review. Source: Prepared by the authors 
Explanation of steps

- Theme identification (step 1): the papers were searched on the Web of Science (WoS) database, with all years included, using the Boolean operator "AND" and were selected by the following terms in the title, abstract and keywords of the papers: "temporary AND immersion AND bioreactor AND system AND micropropagation"; "temporary AND immersion AND system AND micropropagation; temporary AND immersion AND bioreactor AND micropropagation"; "bioreactor AND system AND micropropagation; bioreactor AND micropropagation”. A total of 576 were found, considering only scientific papers (not including books and conference proceedings). It is worth clarifying that the Boolean operator 'AND' was used to ensure that only all words appeared together. The terms were searched only in singular, because it was observed that such search also yielded terms in plural as results.

- Screening (exclusion criteria) (step 2): In all the papers, titles and abstracts were analyzed in order to allow further filtering. Three refining filters were applied, excluding: $1^{\circ}$ ) a) duplicate references - identified more than once in different sources, b) non-related references to the research problem or just tangent the themes of interest. As a consequence, of the 576 papers, 401 were excluded. $2^{\circ}$ ) papers that didn't use TIS and papers that didn't obtain shoots as product of the multiplication stage; of the remaining 175 papers, 44 were excluded. $3^{\circ}$ ) papers that didn't work with tree species; of the remaining 131 papers, 111 were excluded.

- Eligibility and scanning of pre-selected papers (step 3): it was reached 20 papers for research and analysis. These papers were pre-selected for indepth reading and analysis.
- Overall analysis of the papers (bibliometric review) (step 4): by using the metadata generated by Web of Science and the cientometric software CiteSpace (Chen, 2006), the following points were analyzed: countries that published and evolution of publications over the years, publications languages, most cited paper, the frequency of journals where the papers were published, and keywords recurrence in a Word Cloud.

- Systematic review (step 5): the main points of each document were addressed in a table (synthesis matrix) which included: studied species; initial explant; TIS used; best immersion frequency; biological efficacy in TIS comparing to SS / CIS (Semi-Solid / Continuous Immersion Systems) systems; hyperhydricity; ex-vitro acclimation (survival) and author's name. In addition, the main gaps, main contributions and future proposals were also addressed.

\section{Results and Discussion}

\section{Bibliometric review}

Fig. 2 presents the countries and publication's years, in which the larger the font letter (and the bigger the circle next to the country's name) the most publications the country has. Brazil ranked in first as country that publish the most, with 4 papers, followed by South Korea and Spain, with 3 papers each and after Sweden and Turkey, with 2 papers. The other countries published only one paper. As for the language of publication, there is a large predominance of papers in English (75\%). The curve that links some of the countries means that a given paper of one country was cited by another given paper from a different country. Moreover, it is possible to observe different sets of colors in the countries' circles, which represent the publication years of the papers (such colors range in a spectrum depicted in the header of Fig. 2, where cold colors represent the papers with older publications and the warm colors those recently published).

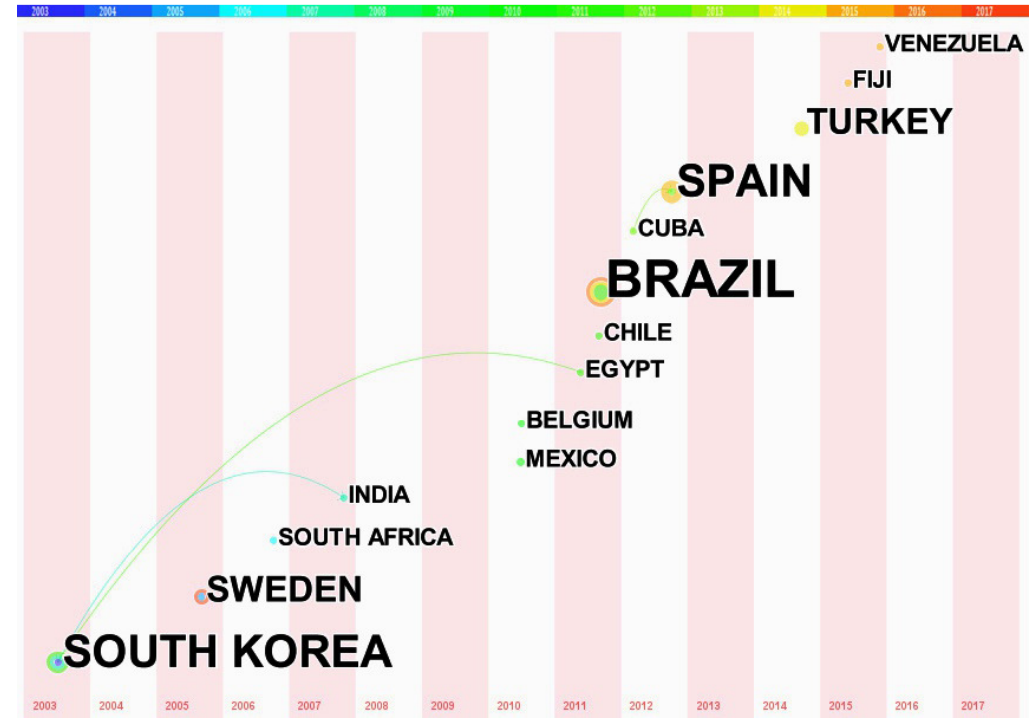

Fig. 2. Countries that published and the evolution of publications over the years. Source: Prepared by the authors on CiteSpace based on Web of Science metadata 
272

Although South Korea is second in relation to publication number, their publications are older compared, for example, to Brazil and Spain that have more recent papers. It's interesting to note that of the 4 papers published by Brazil, 3 of them are by Oliveira et al. (2011a, 2011b, 2014) who worked with the hybrid $E$. grandis $\times E$. urophylla testing several parameters in the RITA ${ }^{\circ}$ bioreactor (www.vitropic.fr).

It was also observed that the first publication dates back to 2003, with the article "Micropropagation of apple rootstock M.9 EMLA using bioreactor" by Chakrabarty $e t$ al. (2003). Also worth highlighting is that such paper is also the most cited article in the sample, with 24 citations.

The largest number of papers was published from the 2010 to the 2015, showing that, although the first reports of TIS usage occurred with the apparatus developed by Harris and Mason (1983), more attention on its use with tree species has occurred decades later. Such evidence may be associated with greater interest on the part of the researchers of the area by this research theme, as well as a greater diffusion of the TIS equipments in experimental laboratories.

Regarding the publication sources, the international journals "Plant Cell, Tissue and Organ Culture" and "Acta Horticulturae" had the largest number of published papers. These journals have great acceptance of studies regarding the tissue culture field, so they are among the best targets for researchers working in the TIS theme.

Finally, Fig. 3 shows the most cited words in the titles, key-words and abstracts of the papers, prepared by using the "Word Frequency Counter" application. The words were chosen for their frequency and relevance on discussions and debates on the theme. It is important to highlight the words: immersion, shoots, bioreactor, culture, medium, temporary, system, explants, micropropagation and RITA ${ }^{\circledR}$.

\section{Systematic review}

In order to carry out the papers' categorization, the analyzes of each of the 20 papers were summarized on Table 1.

Species

The genus Eucalyptus was the most studied among the analyzed documents, being present in $35 \%$ of the total papers. In addition, it was observed that, of these $35 \%$, more than $50 \%$ were realized by research teams located in Brazilian institutions. These numbers may be related not only to the great economic importance associated with the rapid growth, wide adaptability and multipurpose wood of this tree (Bertola, 2014), but also because Brazil is recognized worldwide for its high productivity of planted eucalyptus areas and for being among the world's leading pulp producers, ranking second only behind the United States in 2016 (IBÁ, 2017).

Additionally, in several species - especially in Eucalyptus $s p p$. - TIS cultivation has achieved an increase in multiplication rate and a reduction in multiplication time compared to semi-solid medium cultivations. Castro and González (2002), working with Eucalyptus grandis reached a multiplication rate of 11.5 shoots in 6 weeks of cultivation. Moreover, McAlister et al. (2005) were able to double the multiplication rate by half the time in different clones of Eucalyptus spp.

Although eucalyptus was the most studied species, other species of great economic interest also appeared in the papers, such as apple, followed by chestnut and pistachio (Chakrabarty et al., 2003, 2007; Zhu et al., 2005; Troch et al., 2010; Akdemir et al., 2014; Tilkat et al., 2014; Vidal et al., 2015a).

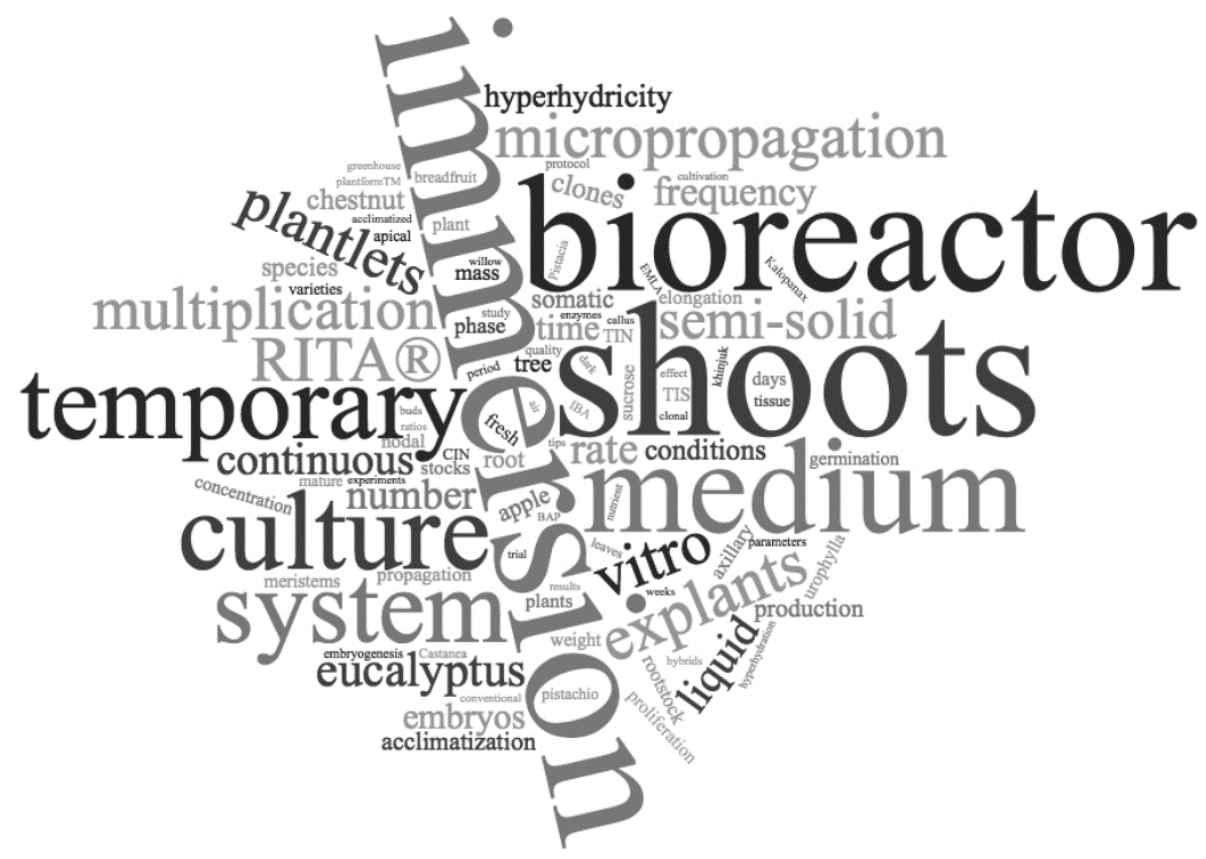

Fig. 3. Word cloud of recurrent key-words on the papers' titles and abstracts. Source: Prepared by the authors using https://www.wordclouds.com 
Table 1. Summary of micropropagation processes using temporary immersion systems

\begin{tabular}{|c|c|c|c|c|c|c|c|}
\hline $\begin{array}{c}\text { Species } \\
\text { (Common } \\
\text { Name) }\end{array}$ & Initial explant & $\begin{array}{c}\text { Temporary Immersion } \\
\text { System }\end{array}$ & $\begin{array}{c}\text { Best } \\
\text { immersion } \\
\text { frequency }\end{array}$ & $\begin{array}{c}\text { Comparation TIS vs } \\
\text { SS } / \mathrm{CIS}^{(1)}\end{array}$ & Hyperhydricity & $\begin{array}{c}\text { Ex-vitro } \\
\text { acclimation } \\
\text { (survival) }\end{array}$ & Citation \\
\hline $\begin{array}{r}\text { Pistacia spp. } \\
\text { (pistachio) }\end{array}$ & $\begin{array}{l}\text { Shoot tips and nodal } \\
\text { buds }\end{array}$ & RITA & $16 \mathrm{~h} / 24 \mathrm{~min}$ & $\begin{array}{c}\text { PR: } 4.04 \text { (/SS; P. vera), } \\
\text { SL: } 1.93 \text { (/SS; P. khinjuk) }\end{array}$ & No & Not reported & $\begin{array}{c}\text { Akdemir et al., } \\
2014\end{array}$ \\
\hline $\begin{array}{c}\text { E. grandis XE. } \\
\text { urophylla; Betula } \\
\text { spp. }\end{array}$ & $\begin{array}{l}\text { Eucalyptus (small } \\
\text { shoot clumps); } \\
\text { Betula spp. (stem of } \\
\qquad 2-3 \mathrm{~cm} \text { ) }\end{array}$ & $\begin{array}{c}\text { TIB (Temporary } \\
\text { Immersion Bioreactor) } \\
\text { - new model of Twin } \\
\text { flask }\end{array}$ & $1 \mathrm{~h} / 1 \mathrm{~min}$ & $\begin{array}{c}\text { PR: } 5.75 \text { (/SS; } \\
\text { Eucalyptus), } 1.75 \text { (/SS; } B . \\
\text { pendula), FW: TIS > SS }\end{array}$ & $\begin{array}{c}\text { Parcial (Betula } \\
\text { pendula) }\end{array}$ & $100 \%$ & Businge et al., 2017 \\
\hline $\begin{array}{c}\text { Malus domestica } \\
\text { Borkh. (apple M.9 } \\
\text { EMLA) }\end{array}$ & Nodal segments & $\begin{array}{c}\text { Ebb \& Flood (Air lift } \\
\text { BTBB and air lift } \\
\text { Column) }\end{array}$ & $6 \mathrm{~h} / 15 \mathrm{~min}$ & $\begin{array}{c}\text { PR: } 0.87 \text { (/SS), SL:0.94 } \\
\text { (/SS), FW: } 0.79 \text { (/SS) }\end{array}$ & $8.24 \%$ & $>90 \%$ & $\begin{array}{l}\text { Chakrabarty et al., } \\
2003\end{array}$ \\
\hline $\begin{array}{l}\text { Malus domestica } \\
\text { Borkh. (apple M.9 } \\
\text { EMLA) }\end{array}$ & $\begin{array}{l}\text { Single-node cuttings } \\
\text { with a single leaf }\end{array}$ & $\begin{array}{l}\text { BTBB (ballon-type } \\
\text { bubble bioreactor) }\end{array}$ & $6 \mathrm{~h} / 15 \mathrm{~min}$ & $\begin{array}{c}\text { PR: } 0.64 \text { (/CIS), SL: } 1.03 \\
\text { (/CIS), FW: } 0.86 \text { (/CIS), } \\
\text { DW } 1.33 \text { (/CIS) }\end{array}$ & $17.7 \%$ & Not reported & $\begin{array}{l}\text { Chakrabarty et al., } \\
2007\end{array}$ \\
\hline Eucalyptus globulus & $\begin{array}{l}\text { Microshoots of } 1.5 \\
\mathrm{~cm}\end{array}$ & $\begin{array}{c}\text { BIT (Escalona et al, } \\
\text { 1999) }\end{array}$ & $12 \mathrm{~h} / 2 \mathrm{~min}$ & PR: $43.2^{(2)}$ & $50.4 \%$ & Not reported & $\begin{array}{l}\text { González et al., } \\
2011\end{array}$ \\
\hline Eucalyptusspp. & Nodal shoots & RITA $^{\circ}$ & $10 \mathrm{~min} / 30 \mathrm{~s}$ & PR: 1.58 (/SS) & Not reported & $91 \%$ & Hajari et al., 2006 \\
\hline $\begin{array}{c}\text { Kalopanax } \\
\text { septembolus (tree } \\
\text { aralia) }\end{array}$ & $\begin{array}{l}\text { Somatic embryos at } \\
\text { the early } \\
\text { cotyledonary stages }\end{array}$ & $\begin{array}{l}\text { Modified column type } \\
\text { bioreactor }\end{array}$ & $4 \mathrm{~h} / 30 \mathrm{~min}$ & PR: 2.9 (/CIS), 1.18 (/SS) & Not reported & $100 \%$ & Kim et al., 2011 \\
\hline $\begin{array}{c}\text { Eucalyptus } \\
\text { camaldulensis }\end{array}$ & $\begin{array}{l}\text { Explants of } 1 \mathrm{~cm} \\
\text { length and two buds }\end{array}$ & $\begin{array}{c}\text { Two glass bottles } \\
\text { (culture medium and } \\
\text { explants) }\end{array}$ & $2 \mathrm{~h} / 15 \mathrm{~min}$ & $\begin{array}{c}\text { PR: } 0.74 \text { (/CIS), SL: } 1 \\
\text { (/CIS) }\end{array}$ & No & $76 \%$ & $\begin{array}{l}\text { Mendonça et al., } \\
2016\end{array}$ \\
\hline $\begin{array}{c}\text { Eucalytus grandis } \times \\
\text { Eucalyptus } \\
\text { urophylla }\end{array}$ & $\begin{array}{l}\text { Apical shoots; } \\
\text { clusters of shoots }\end{array}$ & RITA* & $2 \mathrm{~h} / 8 \mathrm{~s}$ & PR: 12.7, FW: $\sim 0.4 \mathrm{~g}^{(2)}$ & $\sim 10 \%$ & Not reported & $\begin{array}{l}\text { Oliveira et al., } \\
\text { 2011 a }\end{array}$ \\
\hline $\begin{array}{c}\text { Eucalytus grandis } \times \\
\text { Eucalyptus } \\
\text { urophylla }\end{array}$ & Apical shoots & RITA $^{\circ}$ & $2 \mathrm{~h} / 8 \mathrm{~s}$ & $\begin{array}{c}\text { PR: } \sim 2 \text { (/SS), FW: } 2.5 \\
\text { (/SS) }\end{array}$ & $\sim 100 \%$ & Not reported & $\begin{array}{l}\text { Oliveira et al., } \\
2011 \mathrm{~b}\end{array}$ \\
\hline $\begin{array}{c}\text { Eucalytus grandis } \times \\
\text { Eucalyptus } \\
\text { urophylla }\end{array}$ & Apical shoots & RITA* & $2 \mathrm{~h} / 8 \mathrm{~s}$ & PR: $14.37, \mathrm{FW}: 0.49^{(2)}$ & $65.9 \%$ & Not reported & $\begin{array}{l}\text { Oliveira et al., } \\
2014\end{array}$ \\
\hline $\begin{array}{l}\text { Cedrela odorata } \mathrm{L} \text {. } \\
\text { (Spanish red cedar; } \\
\text { cigar box cedar) }\end{array}$ & Adventitious shoots & BioMINT $^{*}$ & $6 \mathrm{~h} / 1 \mathrm{~min}$ & $\begin{array}{l}\text { LS: } 3.67 \text { (/SS), DW: } 10 \\
\quad(/ S S), \text { LR: } 3 \text { (/SS) }\end{array}$ & Not reported & $98 \%$ & $\begin{array}{l}\text { Peña-Ramirez et } \\
\text { al., } 2010\end{array}$ \\
\hline $\begin{array}{l}\text { Tectona grandis } \mathrm{L} . \\
\quad \text { (teak) }\end{array}$ & $\begin{array}{l}\text { Apical shoots with } \\
\text { two pairs of fully } \\
\text { expanded leaves }\end{array}$ & $\begin{array}{l}\text { Based on the two- } \\
\text { vessel system described } \\
\text { by Escalona et al. } \\
\text { (1999) }\end{array}$ & $6 \mathrm{~h} / 40 \mathrm{~s}$ & $\begin{array}{c}\text { PR: } 2.13 \text { (/SS), LS: } 1.19 \\
\text { (/SS) }\end{array}$ & $26 \%$ & $80 \%$ & Quiala et al., 2012 \\
\hline $\begin{array}{c}\text { Artocarpus altilis } \\
\text { (breadfruit) }\end{array}$ & Shoots of $30 \mathrm{~mm}$ & $\begin{array}{l}\text { Bioreactor tilting } \\
\text { immersion liquid } \\
\text { system (Caisson } \\
\text { Laboratories) }\end{array}$ & $\begin{array}{c}\text { Not } \\
\text { determined }\end{array}$ & Not determined & No & $100 \%$ & $\begin{array}{l}\text { Shandil and Tuia, } \\
2015\end{array}$ \\
\hline $\begin{array}{c}\text { Pistacia kbinjuk } \\
\text { (khinjuk pistachio) }\end{array}$ & $\begin{array}{l}\text { Shoot tips and nodal } \\
\text { buds }\end{array}$ & RITA $^{*}$ & $16 \mathrm{~h} / 10 \mathrm{~min}$ & $\begin{array}{c}\text { PR: } 2.24 \text { (/SS), LS: } 0.63 \\
\text { (/SS) }\end{array}$ & $8 \%$ & Not reported & Tilkat et al., 2014 \\
\hline $\begin{array}{l}\text { Castanea sativa } \\
\text { Mill. (chestnut) }\end{array}$ & $\begin{array}{l}\text { Apical and axillary } \\
\text { explants }\end{array}$ & Twin flask system & $24 \mathrm{~h} / 60 \mathrm{~min}$ & LS: TIS > SS & Parcial & Not reported & Troch et al., 2010 \\
\hline $\begin{array}{l}\text { Castanea } \\
\text { spp.(chestnut); } \\
\text { Salix viminalis } \\
\text { (basket willow) }\end{array}$ & $\begin{array}{l}\text { Apical, medium or } \\
\text { basal segments } \\
\text { attached to the basal } \\
\text { callus }\end{array}$ & $\begin{array}{c}\text { Twin flask system } \\
\text { designed by TRAGSA, } \\
\text { RITA and Plantform }^{\circ}\end{array}$ & $\begin{array}{c}4 \text { or } 8 \mathrm{~h} / 3 \\
\min \end{array}$ & $\begin{array}{l}\text { PR: } 1.16 \text { (/SS; Willow, } \\
\text { RITA“and Plantform"), } \\
\text { LS: } 1.54 \text { (/SS; Chestnut, } \\
\text { Plantform") }\end{array}$ & $\begin{array}{c}\text { No (willow); } \\
\text { Parcial (chestnut) }\end{array}$ & $100 \%$ & Vidal et al., 2015a \\
\hline $\begin{array}{l}\text { Castanea sativa } \\
\text { (chestnut) }\end{array}$ & Nodal explants & $\begin{array}{l}\text { RITA; Plantform; } \\
\text { twin flask system }\end{array}$ & $\begin{array}{c}4 \text { or } 8 \mathrm{~h} / 1 \text { or } \\
3 \mathrm{~min}\end{array}$ & PR: TIS $\geq$ SS. & No & $\sim 40$ to $80 \%$ & Vidal et al., 2015b \\
\hline $\begin{array}{l}\text { Psidium guajava } \mathrm{L} \text {. } \\
\quad \text { (guava) }\end{array}$ & $\begin{array}{l}\text { Embryos in the } \\
\text { torpedo and } \\
\text { cotyledonary stages }\end{array}$ & RITA $^{*}$ & $\begin{array}{c}12 \mathrm{~h} / 1 \text { or } 2 \\
\min \end{array}$ & PR: 2.99 (/SS) & Not reported & Not reported & $\begin{array}{c}\text { Vilchez and } \\
\text { Albany, } 2015\end{array}$ \\
\hline $\begin{array}{c}\text { Malus domestica } \\
\text { Borkh. (apple } \\
\text { M26) }\end{array}$ & Shoots & RITA $^{\circ}$ & $1: 30 \mathrm{~h} / 2 \mathrm{~min}$ & PR: $8.1, \mathrm{LS}: 25.8^{(2)}$ & No & $100 \%$ & Zhu et al., 2005 \\
\hline
\end{tabular}


274

\section{Initial explant}

The initial explants that were used to start a liquid culture in TIS were shoot tips, nodal buds, nodal segments, apical, medium or basal segments with basal callus, shoots and somatic embryos in the torpedo or cotyledonary phase.

In different Castanea sativa clones it was observed that basal explants with callus produced more and larger shoots than apical explants and nodal segments (Vidal et al., $2015 \mathrm{~b})$. This greater proliferation of shoots in callus explants may have occurred because unorganized callus cells may have produced adventitious buds that grow and develop in new aerial parts (Grattapaglia and Machado, 1998).

Akdemir et al. (2014) observed a proliferation of multiple shoots from nodal buds of Pistacia vera 'Siirt' when compared to shoot tips, associating this fact to a breakdown of apical dominance and growth stimulus of lateral shoots. On the other hand, in Pistacia khinjuk, the highest shoot forming capacity index (3.12) and the minimum hyperhydration rate $(8 \%)$ were obtained in shoot tips with an immersion frequency of $10 \mathrm{~min}$ every $16 \mathrm{~h}$ (Tilkat et al., 2014)

\section{Temporary Immersion System (TIS)}

In the reports, RITA ${ }^{\circ}$ was the most used TIS system, it was adopted in $45 \%$ of the studies. This predominance can be explained by the fact that RITA ${ }^{\circ}$ was one of the first TIS to be proposed (Alvard et al., 1993), suggesting a greater access of researchers to this system, and it was the first apparatus to receive commercial interest by the French company Vitropic (Lambardi, 2012). RITA is composed of a single container, divided into two compartments through a support of sufficient relative humidity, which separates the propagules from the liquid medium (Georgiev et al., 2014).

In contrast, it was observed that the system Plantform was only used in two studies, which can be explained by the fact that such system has been recently developed (www.plantform.se). Plantform ${ }^{\circledast}$ presents advantages that overcome problems of older bioreactors, such as: greater interior surface area for the cultures growth, suitable size for handling, possibility of gas exchange, and the possibility to place the boxes one over the other for saving culture space, which is very attractive for large scale production (Welander et al., 2014). Also worth of mention is that the cost of implementing the Plantform ${ }^{\circ}$ system is about half of the cost for RITA ${ }^{\oplus}$ (Lambardi, 2012).

\section{Frequency and time of immersion}

The frequency and time of immersion were one of the main parameters studied, appearing in $40 \%$ of the papers. According to Etienne and Berthouly (2002), the frequency and time of immersion are the most decisive parameters for the efficiency of the system, since they determine the nutrients absorption and the control of hyperhydricity. Although such parameter varies considerably (probably due to the great variety of existing species, different micropropagation processes and different immersion systems used), a great part of the studies reported that in smaller immersion intervals there are greater growth in fresh mass and number of shoots, although hyperhydricity is sometimes more severe (Oliveira et al., 2014).
In pistachio, for example, a 16 minutes immersion every 16 hours reduced vitrification and improved proliferation of shoots, when compared to a 16 minutes immersion every 8 hours (Akdemir et al., 2014). Tilkat et al. (2014) observed that repeated trials for immersion frequencies at short time intervals $(10 \mathrm{~min} / 2 \mathrm{~h}, 10 \mathrm{~min} / 4 \mathrm{~h}$ ) showed hyperhydrated explants up to $100 \%$, while in immersions with relatively longer time intervals $(10 \mathrm{~min} / 20 \mathrm{~h})$ this problem was not observed.

\section{Biological efficacy in TIS in comparison to SS and CIS} systems

According to Etienne and Berthouly (2002), when envisaging commercial use of automated TISs, it is important to take into account growth measurements, production and quality of the cultured material, as well as to compare them to the material produced by conventional culture systems. Most of the articles studied here, showed a better efficacy of TIS in relation to SS. Regarding CIS, it was observed in most of the studies that the highest values of growth measures occurred in CIS instead of TIS, but the quality of TIS material generally was higher than that of CIS material.

Akdemir et al. (2014), working with pistachio, obtained in RITA up to 4.4 higher number of shoots, and up to 1.93 longer shoot length than in SS medium, using the optimized parameters (explant type, frequency and immersion time and growth regulators). Businge et al. (2017) evaluated a new model of TIS bioreactor, which consists of a culture vessel and a bottle for holding liquid medium that can be both autoclaved. The culture vessels are placed on shelves situated one level above the medium to facilitate return flow of the medium for the bottle when the pump is switched off. Using this new system the authors obtained a multiplication rate that was 5.75 times greater than the culture in SS with the hybrid E. grandis $\times E$. urophylla, and 1.75 times greater with Betula pendula. On the other hand, for Betula pubescens an increase of 1.5 times in the multiplication rate was observed when the plants were grown in the semi-solid medium and the fresh weight displayed similar patterns to those observed for multiplication rate.

Working with the apple rootstock 'M9 EMLA', Chakrabarty et al. (2003) demonstrated that although the multiplication rate was higher in CIS, in ebb and flood system (a modification of the Twin-Flasks systems), hyperhydricity was reduced. According to the same authors, the higher rate of multiplication in liquid medium can be explained by the fact that, in this system, there is a larger surface area for the absorption of cytokinins which, as a consequence, inhibits the apical dominance of shoots and increases the formation of axillary shoots. Moreover, in the liquid medium the components are taken up by plants with a better translocation through leaves via stomata and aqueous pores (Schöherr, 2006), and are transferred to the growing regions over a shorter distance (De Klerk and Ter Brugge, 2011). Uptake of medium ingredients and plant growth regulators over the whole plant surface improves the growth of plantlets in liquid medium with TIS (Preil, 2005; Quiala et al., 2006; Akdemir et al., 2014). 
Hyperhydrycity

Hyperhydricity - phenomenon whereby shoots become glassy and transparent, with swollen, brittle leaves and stems - has been reported as one of the major problems affecting woody crops in liquid culture systems (Le Roux and Van Staden, 1991; Chakrabarty et al., 2003).

Although hyperhydrycity has been a problem reported in $80 \%$ of TIS papers, some solutions have shown to reduce and even eliminate this phenomenon by the use of some procedures, such as the application of air ventilation into the system, the increment of immersion intervals and decrease of immersion times, and the decrease of cytokinin concentration.

Chakrabarty et al. (2003), comparing the culture of apple rootstock 'M9 EMLA' in the Ebb and Flood system with and without air exchanges inside the bioreactor chamber, observed a reduction of more than $50 \%$ in hyperhydricity in the presence of air. In corroboration to this observation, Etienne and Berthouly (2002) stated that, to achieve effectiveness in TIS, it's necessary to combine ventilation of the plant tissues with intermittent contact between the entire surface of the tissue and the liquid medium.

In Pistachio vera 'Siirt' the increase of the immersion frequency from 8 hours to 16 and 24 hours not only increased the percentage of proliferation (85 and 88\%, respectively), but also prevented the hyperhydricity of the shoots (0\%) (Akdemir et al., 2014).

González et al. (2011) observed that in Eucalytus globulus the hyperhydration of the shoots increases with the simultaneous increase of macronutrients concentration $(25$ to $100 \%$ ) and immersion time (1 to $3 \mathrm{~min}$ ), and also evidenced this phenomenon with the increase of immersion frequency (6 to $48 \mathrm{~h})$.

The frequency and the immersion time are the main factors that influence the proliferation and hyperhydration of shoots, and this physiological disorder can occur by the formation of an aqueous film around the tissues that may interfere with gas exchanges between the outer tissue and the cell surface, since gas diffusion rates are about 10.000 times slower in water than in air (González et al., 2011; Jackson, 2003), a fact that corroborates the results of Chakrabarty et al. (2003), reported above.

Another factor pointed out in the articles as a cause of hyperhydricity was the high concentration of cytokinins in TIS, such as BA. According to Ivanova and Van Staden (2011), higher concentrations of cytokinins can increase the occurrence of vitrification in many species due to their physiological influences and in the development of plants. In Tectona grandis L. it was observed the presence of hyperhydric shoots in the highest concentration of BA used $(6.6 \mu \mathrm{M})$, which impaired shoots proliferation in TIS (Quiala et al., 2012). In E. globulus, the highest percentage of hyperhydration $(61.9 \%)$ occurred in the treatment with 4.4 uM BA when compared to treatments with $2.2(51,4 \%)$ and without BA (45,3\%) (González et al., 2011). In addition to higher concentration of cytokinins in culture medium, it should be taken into account that prolonged exposure times to BA can also lead to a physiological depletion of the material, thus reducing the rate of shoot proliferation in successive subcultures.
Ex-vitro acclimation (survival)

A high level of plant acclimatization was reported in all the studies which acclimated plants derived from liquid culture in TIS. According to Etienne and Berthouly (2002), enhanced acclimatization of the plant material produced in bioreactors has been claimed as one of the main advantages of TIS.

Kalopanax septembolus plantlets grown in CIS exhibited a lower survival rate (75.8\%) when compared to those grown in TIS bioreactors (100\%) (Kim et al., 2011). Plantlets from bioreactors had $100 \%$ average survival in the screenhouse for Samoan ma'afala and Fijian koqo, two breadfruit (Artocarpus altilis) varieties, whilst $83 \%$ survival was observed for plantlets from SS systems (Shandil and Tuia, 2015). It is noteworthy that, as reported by Businge et al. (2017), plants of $B$. pendula that presented hyperhydric symptoms following the culture in TIS, developed healthy and morphologically normal plants when acclimated in $e x-$ vitro conditions. The same was observed by Quiala et al. (2012) in teak plants grown in $4.44 \mu \mathrm{M} \mathrm{BA}$, which presented morpho-physiological disorders during the multiplication stage in TIS but displayed good development and had a good survival rate $(80 \%)$ during acclimatization, suggesting the possibility for the plantlets to revert into a normal morpho-physiological state after transfer to ex-vitro conditions.

It has been reported that plant grown in bioreactors systems are very similar to plants grown in ex-vitro conditions, providing a higher survival rate (Etienne and Berthouly, 2002). Apple rootstock 'M9 EMLA' shoots produced in TIS showed higher photosynthetic rate, maximum quantum yield of photosystem-II and slow but steady rate of nutrient absorption, indicating a higher rate of photomixotrophic metabolism (Chakrabarty et al., 2007).

\section{Conclusions}

Temporary Immersion Systems have shown positive effects on shoot proliferation of many tree species. Plant growth and proliferation rates are generally better than those obtained on semisolid medium and generally present better quality than plants developed in continuous immersion system. In addition, excellent results have been obtained during the acclimatization of plants from TIS.

In the screening of articles, it was observed that from the total number of papers that worked with TIS and obtained shoots as products of the multiplication stage, only 15\% were of tree species, which shows a scarcity of the use of this system in these species. This fact may be related to the hyperhydricity and "recalcitrancy" to classical micropropagation that are main problems affecting woody species, which can discourage the use of this TIS in such species. On the other hand, the interest in this technique is increasing in recent years, as it can be a solution to the problem related to the high content of phenols of such species that, in turn, creates great problems of tissue and medium oxidation, reducing drastically proliferation rates.

Hyperhydricity has always been considered the main problem affecting the permanent culture in liquid medium. Reports on the use of liquid culture in TIS show that is possible to circumvent or, at least, greatly reduce this 
276

problem by controlling the frequency and immersion time, a great point in favor of TIS culture.

One research limitation of this particular study is indeed the small number of papers that compared the efficacy of more than one bioreactor as cultivation system. Of a total of 20 articles only 2 compared more than one bioreactor system (Vidal et al., 2015a; Vidal et al., 2015b). Since the work of Harris and Mason (1983), several TISs have been developed and the interest in this culture technique has progressively increased and shown promising results when compared to the traditional micropropagation system in semi-solid medium. In this way, it is fundamental not only to compare TIS with micropropagation in semi-solid systems, but also to compare different types of TIS and immersion cycles, in order to select best equipment and protocols for each species.

Another point to be taken into account is the large number of works with the RITA ${ }^{\oplus}$ bioreactor, a consequence of the fact that this bioreactor was the first exploited at the commercial level. Today, other bioreactors are available, commercially or by direct contact with those who developed them. They are often very promising, presenting innovative solutions at lower costs. Practical research should move towards the test of such devices with a broad range of species.

TIS can greatly contribute to reduce production costs, in terms of labor, gelling agent, growing time and shelf area. In addition to this fundamental advantage at commercial level, most of the papers analyzed here showed a high survival rate of plants from TIS during ex-vitro acclimatization, a very important fact when working with tree species, since losses during the acclimatization stage are considered one of the main costs of the micropropagation process as a whole.

\section{Acknowledgements}

The authors are grateful to Coordenação de Aperfeiçoamento de Pessoal de Nível Superior (CAPES) and to CNR-IVALSA for the financial support for conducting this research.

\section{Conflicts of Interest}

The authors declare that there are no conflicts of interest related to this article.

\section{References}

Akdemir H, Süzerer V, Onay A, Tilkat E, Ersali Y, Çiftçi YO (2014). Micropropagation of the pistachio and its rootstocks by temporary immersion system. Plant Cell, Tissue and Organ Culture 117:65-76.

Albarrán J, Bertrand B, Lartaud M, Etienne H (2005). Cycle characteristics in a temporary immersion bioreactor affect regeneration, morphology, water and mineral status of coffee (Coffea arabica) somatic embryos. Plant Cell, Tissue and. Organ Culture 81:27-36.

Alvard D, Côte F, Teisson C (1993). Comparison of methods of liquid medium culture for banana micropropagation. Effects of temporary immersion of explants. Plant Cell, Tissue and Organ Culture 32:55-60.
Bertola A (2014). "Eucalipto: Verdades e Mentiras" ["Eucalyptus: Truths and Lies"]. Retrieved 2017 October 23 from http://www.painelflorestal.com.br/base/www/painelflorestal.com.br/ media/attachments/43/43/541b3e9e487dc6724141e01f535f443560 e2a9ddb5ef2_eucalipto-verdades-e-mitos.pdf.

Botelho LLR, Cunha CCA, Macedo M (2011). O método da revisão integrativa nos estudos organizacionais [The integrative review method in organizational studies]. Gestãoe Sociedade 5(11):121-136.

Businge E, Trifonova A, Schneider C, Rödel P, Egertsdotter U (2017). Evaluation of a new temporary immersion bioreactor system for micropropagation of cultivars of eucalyptus, birch and fir. Forests 8(196):1-9.

Castro D, González J (2002). Eucalyptus (Eucalyptus grandis Hill. ex Maiden.) en el sistema de inmersión temporal [Eucalyptus (Eucalyptus grandis Hill, ex Maiden.) in the temporary immersion system] Agricultura Técnica 62(1):68-78.

Chakrabarty D, Hahn EJ, Yoon YJ, Paek KY (2003). Micropropagation of apple rootstock M.9 EMLA using bioreactor. Horticultural, Science and Biotechnology 78(5):605-609.

Chakrabarty D, Dewir YH, Hahn EJ, Datta SK, Paek KY (2007). The dynamics of nutrient utilization and growth of apple root stock 'M9 EMLA' in temporary versus continuous immersion bioreactors. Plant Growth Regulation 51:11-19.

Chen C (2006). CiteSpace II: Detectingand visualizing emerging trends and transient patterns in scientific literature. Journal of the American Society for Information Science and Technology 57(3):359-377.

De Klerk GJ, Ter Brugge J (2011). Micropropagation of dahlia in static liquid medium using slow-release tools of medium ingredients. Scientia Horticulturae 127:542-547.

Dutra LF, Wendling I, Brondani GE (2009). A micropropagação de eucalipto [The micropropagation of eucalyptus]. Pesquisa Florestal Brasileira 58:49-59.

Etienne H, Berthouly M (2002). Temporary immersion systems in plant micropropagation. Plant Cell, Tissue and Organ Culture 69:215-231.

Georgiev V, Schumann A, Pavlov A, Bley T (2014). Temporary immersion systems in plant biotechnology. Engineering in Life Sciences 14:607621.

González R, Rios D, Avillés F, Sánchez-Olate M (2011). Multiplicación in vitro de Eucalyptus globulus mediante sistema de inmersión temporal [In vitro multiplication of Eucalyptus globulus by a temporary immersion system]. Bosque 32(2):147-154.

Grattapaglia D, Machado MA (1998) Micropropagação. In: Torres AC, Caldas LC, Buso JA (Eds). Cultura de Tecidos e Transformação Genética de Plantas. EMBRAPA-CBAB, Brasilia pp 183-260.

Hajari E, Watt MP, Mycock DJ, McAlister B (2006). Plant regeneration from induced callus of improved Eucalyptus clones. South African Journal of Botany 72:195-201.

Harris RE, Mason EBB (1983). Two machines for in vitro propagation of plants in liquid media. Canadian Journal of Plant Science 63(1):311316.

IBÁ (2017). Indústria Brasileira de Árvores [Brazilian Tree Industry]. Retrieved 2017 October 28 from http://iba.org/images/shared/ Biblioteca/IBA_RelatorioAnual2017.pdf. 
Ivanova M, Van Staden J (2011). Influence of gellingagent and cytokinins on the control of hyperhydricity in Aloe polyphylla. Plant Cell, Tissue and Organ Culture 104: 13-21.

Jackson MB (2003). Aeration stress in plant tissue cultures. Bulgarian Journal of Plant Physiology XXVIX(3-4):96-105.

Kim SJ, Dewir YH, Moon HK (2011). Large-scale plantlets conversion from cotyledonary somatic embryos of Kalopanax septemlobus tree using bioreactor cultures. Journal of Plant Biochemistry and Biotechnology 20(2):241-248.

Lambardi M (2012). Micropropagazione in coltura liquida con sistema ad immersione temporanea [Micropropagation in liquid culture with temporary immersion system]. Rivista di Frutticoltura e di Ortofloricoltura 12:32-38.

Le Roux JJ, Van Staden J (1991). Micropropagation and tissue culture of Eucalyptus - A review. Tree Physiology 9:435-77.

McAlister B, Finnie J, Watt MP, Blakeway F (2005). Use of temporary immersion bioreactor system $\left(\mathrm{RITA}^{\circ}\right)$ for production of commercial Eucalyptus clones in Mondi Forest (SA). Plant Cell, Tissue and Organ Culture 81(3):347-358.

Mendonça EG, Stein VC, CarvalhoHH de, Santos BR, Beijo LA, Paiva LV (2016). The use of continuous, temporary immersion bioreactor system and semisolid culture medium for the production of Eucalyptus camaldulensis clones. Ciência Florestal 26(4):1211-1224.

Oliveira ML de, Xavier A, Filho RMP, Reis JP dos (2014). Efeito do intervalo de imersão e de injeção de ar na multiplicação in vitro de Eucalyptus grandis $\times$ Eucalyptus urophylla em biorreator de imersão temporária [Effect of the immersion interval and air injection on in vitro multiplication of Eucalyptus grandis $\times$ Eucalyptus urophylla in temporary immersion bioreactor]. Ciência Florestal 24(1):37-45.

Oliveira ML de, Xavier A, Filho RMP, Otoni WC, Teixeira JB (2011a). Efeitos do meio de cultura e da relação BAP/ANA na multiplicação in vitro de clones de Eucalyptus grandis X E. urophylla em biorreator de imersão temporária [Effects of culture medium and BA/NAA ratio on in vitro multiplication of Eucalyptus grandis $\times E$. urophylla clones in temporary immersion bioreactor]. Revista Árvore 35(6):1207-1217.

Oliveira ML de, Xavier A, Penchel RM, Santos AF (2011b). Multiplicação in vitro de Eucalyptus grandis $\mathrm{x} E$. urophylla cultivado em meio semissólido e em biorreator de imersão temporária [In vitro multiplication of Eucalyptus grandis $\times$ E. urophylla grown in semisolid medium and in temporary immersion bioreactor] Scientia Forestalis 39(31):309-315.

Peña-Ramírez YJ, Juárez-Gómez J, Gómez-López L, Jerónimo-Pérez JL, Gárcia-Sheseña I, González-Rodrígues JA, Robert ML (2010). Multiple adventitious shoot formation in Spanish Red Cedar (Cedrela odorata L.) cultured in vitro using juvenile and mature tissues: an improved micropropagation protocol for a highly valuable tropical tree species. In Vitro Cellular \& Developmental Biology - Plant 46:149-160.
Preil W (2005). General introduction: a personal reflection on the use of liquid media for in vitro culture. In: Preil W, Hvoslef-Eide AK (Eds). Liquid culture systems for in vitro plant propagation. Springer, Berlin pp $1-18$.

Quiala E, Barbón R, Jiménez E, Feria M de, Chávez M, Capote A, Pérez N (2006). Biomass production of Cymbopogon citratus (DC) Stapf., a medicinal plant, in temporary immersion systems. In Vitro Cellular \& Developmental Biology Plant 42(3):298-300.

Quiala E, Cañal M-J, Meijón M, Rodríguez R, Chávez M, Valledor L, ... Feria M de, Barbón R (2012). Morphological and physiological responses of proliferating shoots of teak to temporary immersion and BA treatments. Plant Cell, Tissue and Organ Culture 109:223-234.

Schönherr J (2006). Characterization of aqueous pores in plant cuticles and permeation of ionic solutes. Journal of Experimental Botany 57(11):2471-2491.

Shandil AS, Tuia VS (2015). Micropropagation of breadfruit (A. altilis) enhanced using a bioreactor system. Acta Horticulturae 1101:159-163.

Tilkat E, Süzerer V, Ersali A, Hoser A, Kilinç FM, Tilkat EA, ... Kaplan A (2014). Mass shoot proliferation of Pistacia kbinjuk stocks using temporary immersion bioreactor system (TIS). Acta Horticulturae 1028:145-151.

Troch V, Sapeta H, Werbrouck S, Geelen D, Van Labeke M-C (2010). In vitro culture of chestnut (Castanea sativa Mill.) using temporary immersion bioreactors. Acta Horticulturae 885:383-389.

Vidal N, Correa B, Rial E, Regueira M, Sánchez C, Cuenca B (2015a). Comparison of temporary and continuous immersion systems for micropropagation of axillary shoots of chestnut and willow. Acta Horticulturae 1083:227-233.

Vidal N, Blanco B, Cuenca B (2015b). A temporary immersion system for micropropagation of axillary of hybrid chestnut. Plant Cell, Tissue and Organ Culture 123:229-243.

Vilchez J, Albany N (2015). Determinación de parámetros de cultivo en la germinación de embriones somáticos de Psidium guajava L en sistemas de inmersión temporal de tipo RITA $^{\circ}$ [Determination of culture parameters in the germination of somatic embryos of Psidium guajava $\mathrm{L}$. in temporary immersion systems RITA type]. Revista de la Facultad de Agronomía LUZ32:209-230.

Welander M, Persson J, Asp H, Zhu LH (2014). Evaluation of a new vessel system based on temporary immersion system for micropropagation. Scientia Horticulturae 179:227-232.

Whittemore R, Knafl K (2005). The integrative review: updated methodology.Journal of Advanced Nursing 52(5):546-553.

Zhu L-H, Li X-Y, Welander M (2005). Optimization of growing conditions for the apple rootstock M26 grown in RITA containers using temporary immersion principle. Plant Cell, Tissue and Organ Culture 81:313-318. 